\title{
Cutis marmorata telangiectatica congenita
}

INSERM

\section{Source}

INSERM. (1999). Orphanet: an online rare disease and orphan drug data base. Cutis marmorata telangiectatica congenita. ORPHA:1556

Cutis marmorata telangiectatica congenita (CMTC) is a congenital localized or generalized vascular anomaly characterized by a persistent cutis marmorata pattern with a marbled bluish to deep purple appearance, spider nevus-like telang iectasia, phlebectasia and, occasionally, ulceration and atrophy of the affected skin. 